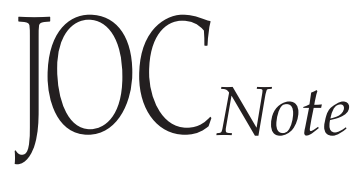

\section{Norbornadiene as an Efficient Hydrogen Scavenger for the Palladium-Catalyzed Conversion of Hydrosilanes to Alkoxysilanes}

\author{
Sundarraj Sudhakar' and Tien-Yau Luh*,t,ł \\ Department of Chemistry, National Taiwan University, \\ Taipei, Taiwan 106, and Institute of Chemistry, \\ Academia Sinica, Nankang, Taipei, Taiwan 115
}

tyluh@chem.sinica.edu.tw

Received May 1, 2002

Abstract: A palladium-catalyzed mild and efficient method for the alcoholysis of hydrosilanes containing a $\mathrm{C}=\mathrm{C}$ bond in the presence of norbornadiene (NBD) is reported. The highly strained NBD acts as a hydrogen scavenger, which abstracts the hydrogen produced during the process, protecting the $\mathrm{C}=\mathrm{C}$ bond from being hydrogenated.

(Isopropoxy)vinylsilanes $\mathbf{1}$ have been shown to be useful precursors of synthetic interest. ${ }^{1}$ Vinylic silyl hydrides $\mathbf{2}$ or siloxane-tethered cyclophanes $\mathbf{3}$ are readily obtained from the corresponding $\mathbf{1}$ that can be easily accessible from the nickel-catalyzed olefination of dithioacetals with ('PrO) $\mathrm{Me}_{2} \mathrm{SiCH}_{2} \mathrm{MgCl}$ (Scheme 1). ${ }^{1,2} \mathrm{Re}$ cently, we were interested in incorporating these vinylsilane moieties into the inorganic-organic hybrid materials by the sol gel technique. Due to the poor reactivity of the isopropoxy moiety under the reaction conditions, the process resulted in the formation of the corresponding cyclic dimer 3 in reasonably good yield. ${ }^{\text {le }}$

A more viable alternative would be to convert the isopropoxy group into a less bulky alkoxy group. However, conventional methods such as the acid-catalyzed direct ethanolysis of $\mathbf{1}$ proved to be unsuccessful, a mixture of low molecular weight oligomers being obtained. We have previously demonstrated that $\mathbf{1}$ can easily be converted into the corresponding vinylic silyl hydride $\mathbf{2}^{1 \mathrm{~b}-\mathrm{d}}$ It is known that the catalytic alcoholysis of hydrosilanes (eq 1 ) is a mild method for the prepara-

$$
\mathrm{R}_{3}^{\prime} \mathrm{Si}-\mathrm{H}+\mathrm{ROH} \underset{\text { cat. }}{\longrightarrow} \mathrm{R}_{3}^{\prime} \mathrm{Si}-\mathrm{OR}+\mathrm{H}_{2}
$$

tion of the alkoxysilanes. ${ }^{3} \mathrm{PdCl}_{2}$ has been recently reported to be an efficient catalyst for this purpose. ${ }^{4}$ Since hydrogen is formed as the byproduct from this

* Author to whom correspondence should be addressed at the Academia Sinica.

† National Taiwan University.

¥ Academia Sinica.

(1) (a) Chen, R.-M.; Weng, W.-W.; Luh, T.-Y. J . Org. Chem. 1995, 60, 3272. (b) Chen, R.-M.; Chien, K.-M.; Wong, K.-T.; J in, B.-Y.; Luh, T.-Y.; Hsu, J .-H.; Fann, W. J . Am. Chem. Soc. 1997, 119, 11321. (c) Chen, R.-M.; Luh, T.-Y. Tetrahedron 1998, 54, 1197. (d) Murthy, V. R K.; Luh, T.-Y. Arkivoc 2001, 2 (10), TG-185G. (e) Sudhakar, S.; Lee, G.-H.; Wang, Y.; Hsu, J .-H.; Luh, T.-Y. J . Organomet. Chem. 2002, 646, 167.

(2) For reviews on the nickel-catalyzed ol efination reactions, see: Luh, T.-Y. Acc. Chem. Res. 1991, 24, 257. Luh, T.-Y. PureAppl. Chem. 1996, 68, 105.

\section{SCHEME 1}
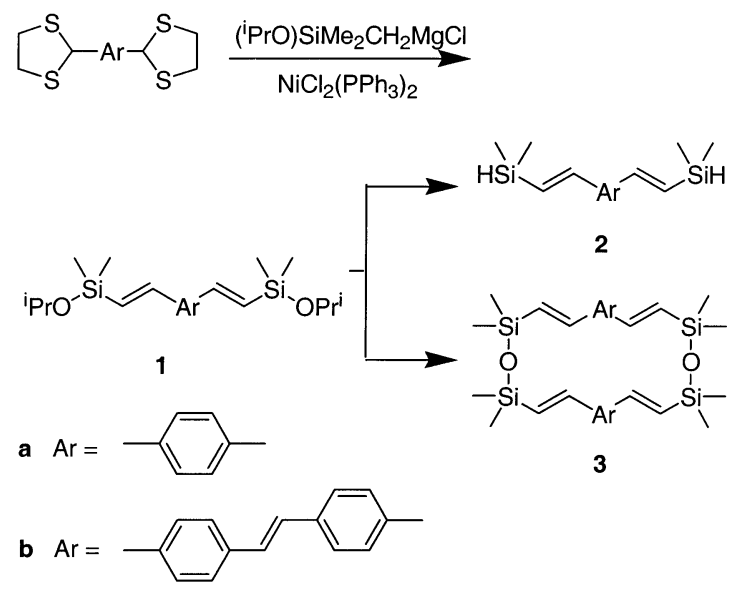

c $\mathrm{Ar}=\longrightarrow$

TABLE 1. $\mathrm{PdCl}_{2}-$ Catalyzed Reaction of 4 and 2 with ROH in the Presence of NBD

\begin{tabular}{cclc}
\hline entry & $\begin{array}{c}\text { reaction } \\
\text { time }(\mathrm{h})\end{array}$ & \multicolumn{1}{c}{ product } & $\begin{array}{r}\% \\
\text { yield }\end{array}$ \\
\hline 1 & 1 & $\mathbf{5 a}(\mathrm{R}=\mathrm{Me})$ & 79 \\
2 & 1 & $\mathbf{5 b}(\mathrm{R}=\mathrm{Et})$ & 76 \\
3 & 1 & $\mathbf{5 c}(\mathrm{R}=\mathrm{i}-\mathrm{Pr})$ & 70 \\
4 & 1 & $\mathbf{5 d}(\mathrm{R}=\mathrm{s}-\mathrm{Bu})$ & 72 \\
5 & 4 & $\mathbf{5 e}(\mathrm{R}=\mathrm{t}-\mathrm{Bu})$ & 65 \\
6 & 1 & $\mathbf{5 f}(\mathrm{R}=\mathrm{Bn})$ & 72 \\
7 & 4 & $\mathbf{5 g}(\mathrm{R}=\mathrm{Ph})$ & $\mathrm{a}$ \\
8 & 2 & $\mathbf{5 h}(\mathrm{R}=\mathrm{Ac})$ & $\mathrm{b}$ \\
9 & 2 & $\mathbf{6 a}$ & 79 \\
10 & 2 & $\mathbf{6 b}$ & 78 \\
11 & 2 & $\mathbf{6 c}$ & $92^{\mathrm{c}}$
\end{tabular}

a Starting material $\mathbf{4}$ was recovered. ${ }^{b}$ Decomposition occurred leading to insoluble solid product, which was not characterized. c Reaction carried out in benzene.

reaction and palladium is an active catalyst for hydrogenation, substrates containing a double bond may also be reduced under these conditions. It is envisaged that a strained olefin would be able to trap the liberated hydrogen so that this side reaction can be avoided. We report here an efficient $\mathrm{PdCl}_{2}$-catalyzed conversion of vinylic silyl hydrides to the corresponding silyl ethers using norbornadiene (NBD) as a hydrogen scavenger.

This strategy was tested by treating $\beta$-styryldimethylsilane (4) with different types of al cohols in the presence

(3) (a) Chang, S.; Scharrer, E.; Brookhart, M. J . Mol. Catal. A 1998 130, 107. (b) Wang, X.; Ellis, W. W.; Bosnich, B. Chem. Commun. 1996 2561. (c) Gregg, T. B.; Cutler, A. R. Organometallics 1994, 13, 1039. (d) Bedard, T. C.; Corey, J . Y. J . Organomet. Chem. 1992, 428, 315. (e) Doyle, M. P.; High, K. G.; Bagher, V.; Pieters, R. J .; Lewis, P.J . Pearson, M. M. J . Org. Chem. 1990, 55, 6082. (f) Haszeldine, R. N.; Parish, R. V.; Riley, B. F. J . Chem. Soc., Dalton Trans. 1980, 705. (g) Archer, N. J.; Haszeldine, R. N.; Parish, R. V. J . Chem. Soc., Dalton Trans. 1979, 695. (h) Corriu, R. J . P.; Moreau, J J . E. J . Organomet. Chem. 1977, 127, 7. (i) Corriu, R. J . P.; M oreau, J . J . E. J . Organomet. Chem. 1976, 120, 337. (j) Corriu, R. J. P.; Moreau, J.J. E. J. Organomet. Chem. 1976, 114, 135. (k) Ojima, I.; Kogure, T.; Nihonyanagi, M.; Kono, H.; I naba, S.; Nagai, Y. Chem. Lett. 1973, 501.

(4) William, J. L.; Rabah, B.; Corinna, K. J . Am. Chem. Soc. 1998, $120,9504$.

10.1021/j0025886z CCC: $\$ 22.00$ C 2002 American Chemical Society Published on Web 08/24/2002 
of 1.5 equiv of NBD and a catalytic amount of $\mathrm{PdCl}_{2}$ (Table 1). After the usual workup, alkoxysilanes 5 were obtained in good yield. No hydrogen evolution was noticed from the reaction, which is in contrast to the conventional systems in which the completion of the reaction was monitored by the cessation of evolved hydrogen. As can be seen from Table 1, the reaction proceeded nicely with primary and secondary alcohols. Longer reaction time was required for tertiary alcohol. Phenol was unreactive under these conditions, starting material $\mathbf{4}$ being recovered. When acetic acid was employed, decomposition occurred, giving an insoluble solid mixture that was not characterized.
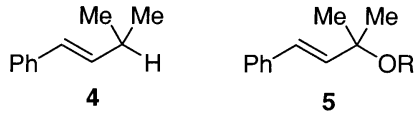

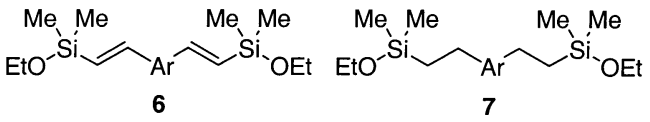
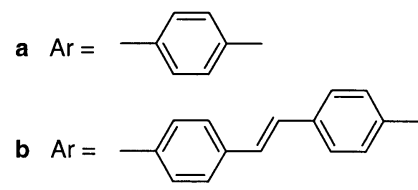

c $\mathrm{Ar}=\longrightarrow$
An extension of this procedure to the synthesis of bisethoxysilane derivatives $\mathbf{6 a}-\mathbf{c}$ proceeded smoothly. Three equivalents of NBD was used to trap the liberated hydrogen leading to $\mathbf{6}$ in satisfactory yield. In the absence of NBD, when $\mathbf{2 a}$ was treated with $\mathrm{PdCl}_{2}$ in $\mathrm{EtOH}$, a $1: 1$ mixture of $\mathbf{6 a}$ and $\mathbf{7}$ was obtained. The results are summarized in Table 1. Bis-ethoxysilanes $\mathbf{6}$ underwent rapid polymerization even at low temperature $\left(-15^{\circ} \mathrm{C}\right)$ in $\mathrm{CDCl}_{3}$. Presumably, a trace amount of acid or water may catalyze decomposition of $\mathbf{6}$.

A terminal vinyl group was also found to be stable under these conditions. Thus, reaction of $\mathbf{2 c}$ in the presence of an equal molar amount of styrene, under the same reaction conditions, afforded $\mathbf{6 c}$ in $92 \%$ yiel d along with the quantitative recovery of styrene ( $>98 \%$ by GC). This observation suggests that NBD could serve as an efficient hydrogen trapping agent and prevent the hydrogenation of a variety of alkenes.

In summary, we have demonstrated a convenient procedure for the synthesis of alkoxysilanes by means of $\mathrm{PdCl}_{2}$-catalyzed alcoholysis of the corresponding silyl hydrides in the presence of NBD. NBD apparently has played a significant role in trapping the liberated hydrogen. No reduction product was obtained at all. A variety of alcohols can be used for this purpose. Further applications of this reaction in organic synthesis and in sol gel chemistry are in progress in our laboratory.

\section{Experimental Section}

General Procedure for the Preparation of 5. To a solution of $4^{1}$ (1 equiv) and NBD (1.5 equiv) in absolute ethanol (15 equiv) under $\mathrm{N}_{2}$ was added a catalytic amount of palladium(II) chloride (0.2 mol \%). The mixture was stirred at room temperature for the desired time. The resulting liquid was removed from the insoluble palladium salts by filtering through a filter cartridge, followed by removal of the solvent, NBD, and its hydrogenated products in vacuo to yield the title compounds.

General Procedure for the Preparation of the Different Bis[ $\beta$-(ethoxydimethylsilyl)vinyl]arenas $6 \mathbf{a}-\mathbf{c}$. In a manner similar to that described in the general procedure for $\mathbf{5 a}-\mathbf{f}$, a mixture of bis[ $\beta$-(dimethylsilyl)vinyl]arenes $\mathbf{2 a}-\mathbf{c}^{1}$ (1 equiv), NBD (3.0 equiv), a catalytic amount of palladium(II) chloride (0.4 mol \%), and absolute ethanol (15 equiv) in dry THF or benzene under $\mathrm{N}_{2}$ was stirred at room temperature for $2 \mathrm{~h}$. (Note: F or the preparation of $\mathbf{6 a}, 30$ equiv of ethanol was used and no THF was added as compound $\mathbf{2 a}$ was easily soluble in ethanol.) After the usual workup, $\mathbf{6}$ was obtained.

Control experiments with styrene were carried out in a similar manner.

Compound 5a: ${ }^{1} \mathrm{H}$ NMR $\left(400 \mathrm{MHz}, \mathrm{CDCl}_{3}\right) \delta 0.26(\mathrm{~s}, 6 \mathrm{H})$, $3.46(\mathrm{~s}, 3 \mathrm{H}), 6.41(\mathrm{~d}, \mathrm{~J}=19.3 \mathrm{~Hz}, 1 \mathrm{H}), 6.99(\mathrm{~d}, \mathrm{~J}=19.3 \mathrm{~Hz}, 1$ $\mathrm{H}), 7.25-7.29(\mathrm{~m}, 1 \mathrm{H}), 7.30-7.36(\mathrm{~m}, 2 \mathrm{H}), 7.42-7.48(\mathrm{~m}, 2$

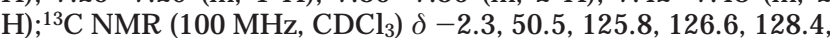
128.6, 137.9, 145.8; IR (neat) 3064, 3029, 2963, 2908, 2834, 1605, 1254, 1194, 1089, 993, 846, 783, $734 \mathrm{~cm}^{-1}$; HRMS m/e (EI) for $\mathrm{C}_{11} \mathrm{H}_{16} \mathrm{OSi}(\mathrm{M})^{+}$calcd 192.0970, found 192.0967

Compound 5b: ${ }^{1} \mathrm{H}$ NMR $\left(400 \mathrm{MHz}^{\left.-\mathrm{CDCl}_{3}\right)} \delta 0.26(\mathrm{~s}, 6 \mathrm{H})\right.$, $1.2(\mathrm{t}, \mathrm{J}=7.0 \mathrm{~Hz}, 3 \mathrm{H}), 3.71(\mathrm{q}, \mathrm{J}=7.0 \mathrm{~Hz}, 2 \mathrm{H}), 6.42(\mathrm{~d}, \mathrm{~J}=$ $19.3 \mathrm{~Hz}, 1 \mathrm{H}), 6.98(\mathrm{~d}, \mathrm{~J}=19.3 \mathrm{~Hz}, 1 \mathrm{H}), 7.25-7.28(\mathrm{~m}, 1 \mathrm{H})$, 7.29-7.36 (m, $2 \mathrm{H}), 7.41-7.48(\mathrm{~m}, 2 \mathrm{H}) ;{ }^{13} \mathrm{C} N M R(100 \mathrm{MHz}$, $\left.\mathrm{CDCl}_{3}\right) \delta-1.7,18.5,58.5,126.5,126.6,128.3,128.5,138.0,145.5$ IR (neat) 3065, 3029, 2971, 2901, 2878, 1608, 1254, 1108, 1080, $991,946,838,782,735 \mathrm{~cm}^{-1}$; HRMS m/e(EI) for $\mathrm{C}_{12} \mathrm{H}_{18} \mathrm{OSi}(\mathrm{M})^{+}$ calcd 206.1127, found 206.1125.

Compound 5c: ${ }^{1 \mathrm{H}} \mathrm{NMR}\left(400 \mathrm{MHz}, \mathrm{CD}_{2} \mathrm{Cl}_{2}\right) \delta 0.25(\mathrm{~s}, 6 \mathrm{H})$, $1.16(\mathrm{~d}, \mathrm{~J}=6.1 \mathrm{~Hz}, 6 \mathrm{H}), 4.06$ (sept, J $=6.1 \mathrm{~Hz}, 1 \mathrm{H}), 6.46(\mathrm{~d}$, $\mathrm{J}=19.3 \mathrm{~Hz}, 1 \mathrm{H}), 6.99(\mathrm{~d}, \mathrm{~J}=19.3 \mathrm{~Hz}, 1 \mathrm{H}), 7.25-7.28(\mathrm{~m}, 1$ H), $7.29-7.36(\mathrm{~m}, 2 \mathrm{H}), 7.41-7.48(\mathrm{~m}, 2 \mathrm{H}) ;{ }^{13} \mathrm{C} N \mathrm{MR}(100 \mathrm{MHz}$, $\left.\mathrm{CD}_{2} \mathrm{Cl}_{2}\right) \delta-0.9,26.2,65.7,127.1,127.9,128.8,129.1,138.8$ 145.6; IR (neat) 3065, 3029, 2974, 2935, 2878, 1608, 1253, 1174, 1127, 1028, 993, 883, 849, 781, $736 \mathrm{~cm}^{-1}$; HRMS m/e (EI) for $\mathrm{C}_{13} \mathrm{H}_{20} \mathrm{OSi}(\mathrm{M})^{+}$calcd 220.1283, found 220.1276 .

Compound 5d: ${ }^{1} \mathrm{H}$ NMR $\left(400 \mathrm{MHz} \mathrm{CDCl}_{3}\right) \delta 0.26(\mathrm{~s}, 6 \mathrm{H})$, $0.87(\mathrm{~d}, \mathrm{~J}=7.4 \mathrm{~Hz}, 3 \mathrm{H}), 1.14(\mathrm{~d}, \mathrm{~J}=6.1 \mathrm{~Hz}, 3 \mathrm{H}), 1.35-1.55$ $(\mathrm{m}, 2 \mathrm{H}), 3.70-3.80(\mathrm{~m}, 1 \mathrm{H}), 6.44(\mathrm{~d}, \mathrm{~J}=19.3 \mathrm{~Hz}, 1 \mathrm{H}), 6.96(\mathrm{~d}$, $J=19.3 \mathrm{~Hz}, 1 \mathrm{H}), 7.24-7.26(\mathrm{~m}, 1 \mathrm{H}), 7.29-7.36(\mathrm{~m}, 2 \mathrm{H}), 7.41-$ $7.47(\mathrm{~m}, 2 \mathrm{H}) ;{ }^{13} \mathrm{C}$ NMR $\left(100 \mathrm{MHz}^{2} \mathrm{CDCl}_{3}\right) \delta-1.11,-1.06,10.3$, $23.4,32.3,70.3,126.6,127.3,128.3,128.5,138.1,145.2$; IR (neat) $3065,3029,2970,2934,2879,1608,1253,1172,1133,1051$, $1012,993,850,782,737 \mathrm{~cm}^{-1}$; HRMS m/e (EI) for $\mathrm{C}_{14} \mathrm{H}_{22} \mathrm{OSi}$ $(\mathrm{M})^{+}$calcd 234.1440, found 234.1431.

Compound 5e: ${ }^{1} \mathrm{H}$ NMR $\left(400 \mathrm{MHz} \mathrm{CDCl}_{3}\right) \delta 0.26(\mathrm{~s}, 6 \mathrm{H})$, $1.27(\mathrm{~s}, 9 \mathrm{H}), 6.47(\mathrm{~d}, \mathrm{~J}=19.2 \mathrm{~Hz}, 1 \mathrm{H}), 6.92(\mathrm{~d}, \mathrm{~J}=19.2 \mathrm{~Hz}, 1$ H), 7.23-7.28 (m, $1 \mathrm{H}), 7.29-7.36(\mathrm{~m}, 2 \mathrm{H}), 7.42-7.47(\mathrm{~m}, 2$ $\mathrm{H}) ;{ }^{13} \mathrm{C}$ NMR $\left(100 \mathrm{MHz}^{-} \mathrm{CDCl}_{3}\right) \delta 1.2,32.1,72.6,126.5,128.1$, $128.5,129.5,138.3,143.9$; IR (neat) $3065,3029,2977,2908,2878$, $1608,1366,1253,1198,1050,1026,993,883,844,781,738 \mathrm{~cm}^{-1}$ HRMS m/e (EI) for $\mathrm{C}_{14} \mathrm{H}_{22} \mathrm{OSi}(\mathrm{M})^{+}$calcd 234.1440, found 234.1433.

Compound 5f: ${ }^{1 \mathrm{H}} \mathrm{NMR}\left(400 \mathrm{MHz}, \mathrm{CDCl}_{3}\right) \delta 0.29(\mathrm{~s}, 6 \mathrm{H})$, $4.74(\mathrm{~s}, 2 \mathrm{H}), 6.42(\mathrm{~d}, \mathrm{~J}=19.3 \mathrm{~Hz}, 1 \mathrm{H}), 7.00(\mathrm{~d}, \mathrm{~J}=19.3 \mathrm{~Hz}, 1$ H), 7.23-7.28 (m, $2 \mathrm{H}), 7.29-7.36(\mathrm{br} \mathrm{m}, 6 \mathrm{H}), 7.46-7.40(\mathrm{~m}, 2$ $\mathrm{H}) ;{ }^{13} \mathrm{C} N M R\left(100 \mathrm{MHz}^{2} \mathrm{CDCl}_{3}\right) \delta-1.6,65.0,126.2,126.61$, $126.64,127.1,128.3,128.4,128.5,137.9,140.8,145.8$; IR (neat) 3066, 3032, 2996, 2962, 2900, 2874, 1606, 1255, 1207, 1092, 1066, 1030, 991, 848, 781, $731 \mathrm{~cm}^{-1}$; HRMS m/e(EI) for $\mathrm{C}_{17} \mathrm{H}_{20^{-}}$ OSi $(M)^{+}$calcd 268.1283 , found 268.1269 .

Compound 6a: ${ }^{1 \mathrm{H}} \mathrm{NMR}\left(400 \mathrm{MHz}, \mathrm{CDCl}_{3}\right) \delta 0.26(\mathrm{~s}, 12 \mathrm{H})$, $1.20(\mathrm{t}, \mathrm{J}=7.0 \mathrm{~Hz}, 6 \mathrm{H}), 3.70(\mathrm{q}, \mathrm{J}=7.0 \mathrm{~Hz}, 4 \mathrm{H}), 6.43(\mathrm{~d}, \mathrm{~J}=$ $19.3 \mathrm{~Hz}, 2 \mathrm{H}), 6.96(\mathrm{~d}, \mathrm{~J}=19.3 \mathrm{~Hz}, 2 \mathrm{H}), 7.41(\mathrm{~s}, 4 \mathrm{H}) ;{ }^{13} \mathrm{C} N M R$ $\left(100 \mathrm{M} \mathrm{Hz} \mathrm{CDCl}_{3}\right) \delta-1.7,18.5,58.5,126.78,126.80,137.9,138.0$ 145.0; IR (neat) 2970, 2928, 2901, 2878, 1606, 1253, 1109, 1080, 989, 946, 840, $795 \mathrm{~cm}^{-1}$; HRMS m/e (EI) for $\mathrm{C}_{18} \mathrm{H}_{30} \mathrm{O}_{2} \mathrm{Si}_{2}(\mathrm{M})^{+}$ calcd 334.1784, found 334.1749.

Compound 6b: ${ }^{1} \mathrm{H}$ NMR $\left(300 \mathrm{MHz} \mathrm{CDCl}_{3}\right) \delta 0.26(\mathrm{~s}, 12 \mathrm{H})$, $1.20(\mathrm{t}, \mathrm{J}=7.0 \mathrm{~Hz}, 6 \mathrm{H}), 3.71(\mathrm{q}, \mathrm{J}=7.0 \mathrm{~Hz}, 4 \mathrm{H}), 6.43(\mathrm{~d}, \mathrm{~J}=$ 


\section{JOCNote}

$19.2 \mathrm{~Hz}, 2 \mathrm{H}), 6.96(\mathrm{~d}, \mathrm{~J}=19.2 \mathrm{~Hz}, 2 \mathrm{H}), 7.09(\mathrm{~s}, 2 \mathrm{H}), 7.54-$ $7.35(\mathrm{~m}, 8 \mathrm{H}) ;{ }^{13} \mathrm{C}$ NMR $\left(100 \mathrm{MHz}, \mathrm{CDCl}_{3}\right) \delta-1.7,18.5,58.5$, $126.5,126.7,126.8,127.0,128.4,137.3,145.0$; IR (neat) 3030 2966, 2927, 2876, 1604, 1514, 1254, 1108, 1079, 946, 840, 807 $776 \mathrm{~cm}^{-1}$; HRMS m/e (EI) for $\mathrm{C}_{24} \mathrm{H}_{34} \mathrm{O}_{2} \mathrm{Si}_{2}(\mathrm{M})^{+}$calcd 436.2254, found 436.2248 .

Compound 6c: ${ }^{1} \mathrm{H}$ NMR $\left(200 \mathrm{MHz} \mathrm{CDCl}_{3}\right) \delta 0.27(\mathrm{~s}, 12 \mathrm{H})$ $1.21(\mathrm{t}, \mathrm{J}=7.0 \mathrm{~Hz}, 6 \mathrm{H}), 3.72(\mathrm{q}, \mathrm{J}=7.0 \mathrm{~Hz}, 4 \mathrm{H}), 6.46(\mathrm{~d}, \mathrm{~J}=$ $19.2 \mathrm{~Hz}, 2 \mathrm{H}), 7.01(\mathrm{~d}, \mathrm{~J}=19.2 \mathrm{~Hz}, 2 \mathrm{H}), 7.40-7.65(\mathrm{~m}, 8 \mathrm{H})$; I R (neat) 3023, 2964, 2897, 1604, 1495, 1394, 1251, 1107, 1077, 990 , $945,836,791 \mathrm{~cm}^{-1}$.
Acknowledgment. This work was supported by the National Science Council and the Ministry of Education of the Republic of China. The authors also wish to thank Prof. Robert J . P. Corriu, Université Montpellier, F rance, for stimulating discussions.

Supporting I nformation Available: ${ }^{13} \mathrm{C}$ NMR spectra for $\mathbf{5 a}-\mathbf{f}$ and $\mathbf{6 a}, \mathbf{b}$. This material is available free of charge via the Internet at http://pubs.acs.org.

J $0025886 Z$ 